\title{
PRAVNA REGULACIJA POLOŽAJA LOBISTA U SJEDINJENIM AMERIČKIM DRŽAVAMA
}

Prof. dr. sc. Sanja Barić*

Ana Acinger, mag. iur.**

\author{
UDK 328.184(73) \\ https://doi.org/10.30925/zpfsr.39.2.7 \\ Ur.: 24. studenoga 2017. \\ Pr.: 28. prosinca 2017. \\ Prethodno priopćenje
}

\begin{abstract}
Sažetak
Polazeći od prepoznavanja važnosti lobiranja u suvremenim demokratskim zemljama i njegovoj nezaobilaznosti u procesu donošenja odluka od nižih (lokalnih) do najviših razina vlasti, autorice prikazuju lobiranje u Sjedinjenim Američkim Državama. Upravo je ondje zarana prepoznata važnost lobiranja, a osobito njegove regulacije radi postizanja transparentnosti. Autorice se osvrću na relevantne propise kojima je reguliran pravni položaj lobista, $i$ to od samih začetaka do današnjih dana, prateći i analizirajući njihove prednosti i nedostatke, a osobito u kontekstu društvene zbilje kao poticaja za donošenje daljnjeg zakonodavstva. Ujedno se osvrću na odnos politike prema regulaciji lobiranja, kao i odnos lobiranja i temeljnih ljudskih prava zajamčenih Prvim amandmanom Ustava SAD-a.
\end{abstract}

Ključne riječi: lobiranje, Sjedinjene Američke Države, ustavna prava, transparentnost, ljudska prava.

\section{1. $U V O D$}

Pravo na lobiranje ili zagovaranje interesa, kao donekle širi pojam, zajamčeno je i ustavom pojedine države kao njenim najvišim pravnim aktom, ali i konvencijama, preporukama te raznim drugim dokumentima najvažnijih međunarodnih institucija. ${ }^{1}$

* Dr. sc. Sanja Barić, redovita profesorica Sveučilišta u Rijeci, Pravnog fakulteta; sbaric@pravri. $\mathrm{hr}$.

** Ana Acinger, mag. iur., odvjetnička vježbenica; ana.acinger@gmail.com.

1 Primjerice, izvješće Ujedinjenih naroda (preciznije, Accountability United Nations Global Compact Towards Responsible Lobbying iz 2005. godine), dokument Venecijanske komisije The Legal Framework for the Regulation of Lobbying in the Council of Europe Member States, Preporuka Parlamentarne skupštine 1908 iz 2010. godine o lobiranju u demokratskome društvu (Parliamentary Assembly Recommendation 1908 (2010) on lobbying in a democratic society), Rezolucija Parlamentarne skupštine Vijeća Europe 1774 iz 2010. godine o izvaninstitucijskim akterima u demokratskom sustavu te prateće Izvješće 12278 (Parliamentary Assembly Resolution 1744 (2010) on extra-institutional actors in the democratic system, and accompanying Report Doc. 12278), Preporuka Parlamentarne skupštine 2019 iz 2013. godine o korupciji kao prijetnji vladavini prava te prateće Izvješće 13228 (Parliamentary Assembly 
Riječju, lobiranje je jedna od temeljnih, a svakako nezaobilazna sastavnica u procesu donošenja odluka, iz koje koristi crpe i donositelji odluka budući da lobisti prezentiraju argumentiran set podataka te donekle pružaju povratnu informaciju donositeljima odluka o tomu kako se pojedina pravila odražavaju na njihove adresate u praksi. Iako je danas riječ o profesiji u kojoj se ponegdje, a posebice u Sjedinjenim Američkim Državama, godišnje okreću (pa i zgrću) milijarde dolara, put prema afirmaciji lobiranja i njegovoj pravnoj regulaciji nije bio nimalo lak, osobito u odnosu na začetke pravne regulacije. Tako, primjerice u devetnaestomu stoljeću lobiranje ne samo da nije bilo zasebno uređeno, već je u saveznim državama Georgiji i Kaliforniji smatrano kaznenim djelom. ${ }^{2}$ Stoga je zanimljiva dinamika razvijanja regulacije pravnog položaja lobista, od prvoga takvog zakonskog akta do današnjih dana, što je bitno u kontekstu težine promjena slova zakona u SAD-u, tj. da se zakonski akti vrlo teško i sporo mijenjaju, pa su i danas na snazi pojedine odredbe prvih zakona kojima je lobiranje (bilo) regulirano. Vrlo je bitan i odnos prema lobiranju u političkoj zbilji i zbog senzacionalizma u američkim medijima, kojim se, pokazat će se, nerijetko stvaraju temelji za daljnju regulaciju i zbog političke odgovornosti kao koncepta političke kulture te zemlje. Lobiranje je implicitno zajamčeno Ustavom Sjedinjenih Američkih Država, a doseg i definicija danog pojma bili su nerijetko predmetom odlučivanja Vrhovnog suda. Trenutačno postoje oprečne težnje u kontekstu odnosa (striktnije) regulacije lobiranja i ljudskih prava, oboje eksplicitno ili implicitno zajamčenih Prvim amandmanom.

Rad je koncipiran na način da se u prvom dijelu razmatraju različite definicije, vrste i osnovni problemi vezani uz lobiranje kao djelatnost utjecanja na donošenje političkih odluka, a kako bi se omogućilo razumijevanje kompleksnosti ovog pojma. Budući da su Sjedinjene Američke Države kolijevka pravne regulacije lobiranja, autorice u drugom dijelu rada pružaju iscrpan prikaz povijesnog razvitka zakonskog tretmana, ali, još važnije, i prakse koja počesto u bitnom odstupa od zamišljenoga modela. U posljednjem dijelu razmatraju se suvremene tendencije te se ocrtavaju okviri/granice koje zaštićena sfera ljudskih prava postavlja budućim zakonskim rješenjima vezanim uz materiju lobiranja.

\section{POJAM „LOBIRANJE“}

\subsection{Problematika definiranja lobiranja}

Budući da je lobiranje složen proces koji obuhvaća niz aktera i djelatnosti, pojedini se autori pri definiranju lobiranja koncentriraju na različite aspekte lobiranja, rezultat čega je izostanak opće, prevladavajuće definicije danog pojma. U jednom priručniku za odnose s javnošću lobiranje se odnosi na ,interesne skupine i njihove predstavnike

Recommendation 2019 (2013) on corruption as a threat to the rule of law, and accompanying Report Doc. 13228;), Cecchini Report Europske unije, Lobbyists, Governments and Public Trust, Implementing the OECD Principles for Transparency and Integrity in Lobbying, vol. 3., 2014. i sl.

2 Prema: Priceonomics, When Lobbying was Illegal, dostupno na: https://priceonomics.com/ when-lobbying-was-illegal/, posjećeno 28.10.2017. 
čiji je cilj utjecati na odluke ili mišljenje nekog vladajućeg ili korporativnog tijela, tzv. establišmenta, odnosno djelovati na predstavnike ili zastupnike vlasti ili korporacije da (ne) proguraju neko mišljenje, zakon ili izmijene svoja stajališta i tako budu od koristi za onoga tko lobira, ${ }^{\text {“3 }}$ dok se u drugom na lobiranje gleda kao „specijalizirani dio odnosa s javnošću čija je svrha uspostavljanje i održavanje odnosa s državnom vlasti, poglavito s ciljem utjecaja na donošenje zakona i propisa. ${ }^{“ 4}$

Također, ,dostupni stručni radovi pokazuju da još uvijek nema općeprihvaćene, precizne i konzistentne definicije tog termina, kao i da se javlja problem njegova razlikovanja od srodnih pojmova, kao što su government relations (odnosi s vladom), public relations (odnosi s javnošću) ili public affairs (javni poslovi). (...) Imajući u vidu najčešće spominjane elemente definicija, lobiranje se općenito može razumjeti kao legitimno demokratsko nastojanje pojedinca, interesnih skupina ili vlada, da individualno ili udruženi u koalicije utječu na oblikovanje ili provedbu određenih javnih politika u nacionalnim ili nadnacionalnim okvirima kako bi ostvarili željene ciljeve." ${ }^{\text {"5 }}$ Pojam lobiranja i lobista te iznimke od navedenih pojmova, različito se definiraju u svih pedeset država Sjedinjenih Američkih Država ${ }^{6}$

Lobiranje možemo promatrati kao umijeće uvjeravanja. Lester Milbrath, „otac istraživanja o lobiranju“ još je šezdesetih godina prošloga stoljeća definirao lobiranje iz komunikacijske perspektive, odnosno tvrdio je da je lobiranje u potpunosti „komunikacijski proces" ${ }^{\text {"7 }}$ budući da je jedino sredstvo utjecaja ili promjene upravo uvjeravanje. Preko četrdeset godina kasnije, 2005. godine, Dondero i Lunch definiraju lobiranje kao „dvosmjerni komunikacijski proces“8 te smatraju lobiste izvrsnim sugovornicima sa zakonodavcem, smatrajući ih posrednicima između glasača i zakonodavca.

Vlahović i Jelić ${ }^{2}$ upozoravaju na distinkciju u američkom i europskom poimanju pojma lobiranje. Naime, ,u američkim definicijama često je prisutan opis lobističkog utjecaja na sve tri grane vlasti - zakonodavnu, izvršnu i sudbenu, dok europske definicije uzimaju u obzir klasični pristup lobiranju koji ga povezuje samo sa zakonodavnom i izvršnom vlasti. " ${ }^{10}$ Uzevši u obzir elemente ove definicije, isti autori definiraju profesionalno lobiranje kao ,proces pisanog ili usmenog djelovanja prema predstavnicima zakonodavne i izvršne vlasti te ostalim tijelima javne vlasti

3 Osredečki, Eduard, Odnosi s javnošću, Naklada Edo, Zagreb, 1995., str. 101.

4 Cutlip, Scott M., Center, Allen H., Broom, Glen M., Odnosi s javnošću, 8. izd., Mate, Zagreb, 2003., str. 19.

5 Vidačak, Igor, Lobiranje, Interesne skupine i kanali utjecaja u Europskoj uniji, Planetopija, Zagreb, 2007., str. 147.

6 Detaljan prikaz različitih definicija pojma dostupan je na: http://www.ncsl.org/research/ ethics/50-state-chart-lobby-definitions.aspx, posjećeno 10.06.2017.

7 Tusinski Berg, Kati, Finding Connections Betwen Lobbying, Public Relations and Advocacy, Public Relations Jurnal, vol. 3., br. 3., 2009., dostupno na:

http://epublications.marquette.edu/cgi/viewcontent.cgi?article=1081\&context=comm_fac, posjećeno 10.06.2017., str. 2.

8 Loc. cit.

9 Vlahović, Natko, Jelić, Bruno, Profesionalni lobist, priručnik o interesnom zagovaranju, M.E.P., Zagreb, 2015., str. 17.

10 Loc. cit. 
na državnoj razini i na razini jedinica lokalne i područne samouprave radi utjecaja na zakonodavni proces, javne politike i administrativne odluke."11 Ujedno je važno naglasiti da se lobiranje danas shvaća kao složeni proces sastavljen od mnogih komponenti (uključujući pripreme, istraživanja, izradu studija i sl.), a ne više kao ponajprije komunikacijski proces.

Zašto je uopće toliko bitno definirati lobiranje? Važnost te definicije počiva na profesionalizaciji ove djelatnosti te njenoj legitimaciji u suvremenim demokratskim poredcima. Uz to, lobiranje gledano kao proces, kao zagovaranje i/ili ispunjenje određenih partikularnih interesa, može biti donekle suprotstavljeno idealnoj ideji opće volje (pa čak i općem biračkom pravu), odnosno, konkretnije, interesima većine građana koji mogu biti na neki način pogođeni ostvarivanjem lobističkih interesa manjine. Posljedično, vrlo je bitno da je lobiranje transparentno, odnosno da se točno zna tko lobira za koga i koliko je za to plaćen. Registri lobista imaju upravo tu funkciju: osiguranje uvida javnosti, a sve radi povećanja povjerenja u profesiju lobiranja te ukazivanja na bitno razlikovanje djelatnosti lobiranja od korupcije, s kojom se, ova aktivnost nerijetko uspoređuje, ako ne i poistovjećuje. Naime, kako su Vlahović i Jelić zamijetili, a citirajući Marka Roma, profesora sa sveučilišta Georgetown, „davati novac da se nešto napravi je ilegalno. Razgovarati s nekim da se nešto napravi - to nije ilegalno. Problem je što postoje različiti načini na koje novac ulazi u politiku, čineći te granice sve teže podložnima definiranju. "12

Prema Kašćelanu, lobiranje se definira „,kao aktivnost koja ima za cilj mijenjanje postojećih pravila i strategija, dok, s druge strane, korupcija predstavlja pokušaj da se zaobiđu postojeća pravila i procedure“. ${ }^{13}$ Bitno je osvijestiti je da je, u pravilu, lobiranje u svom najvećem dijelu usmjereno na donošenje općih pravnih akata, dakle onih koji u konačnici vrijede za sve jednako, tako da pod istim uvjetima svi imaju jednake prilike i mogućnosti. S druge strane, koruptivna djelovanja imaju za cilj zadovoljavanje partikularnih, specifičnih interesa, čime neminovno dolazi do obolijevanja čitavog sustava i stavljanja adresata određenih pravnih akata u različit, nejednak položaj. Kašćelan čak smatra da lobiranje ,predstavlja borbu protiv korupcije na taj način što će se aktivnosti, koje su izvor korupcije, staviti u zakonske okvire, koje će država moći kontrolirati“" ${ }^{14}$

\subsection{Vrste lobiranja}

Kao što ne postoji općeprihvaćena definicija lobiranja, tako ne postoji ni univerzalna podjela lobiranja na njegove vrste. U načelu se mogu izdvojiti četiri osnovne, glavne vrste lobiranja: „lobiranje javnih politika, zakonodavno lobiranje, prostorno-plansko lobiranje i lobiranje javnih nabava“. ${ }^{15}$ Ne ulazeći podrobnije u

11 Loc. cit.

12 Vlahović, N., Jelić, B., op. cit., str. 31. i Young, Jeffrey, Lobbying Regulated to Prevent Abuse in US, Voa News, 23. 8. 2010., dostupno na: https://www.voanews.com/a/lobbying-regulatedto-prevent-abuse-in-us-101407789/174277.html, posjećeno 10.06.2017.

13 Kašćelan, Balša, Pravni okviri lobiranja, Izazovi evropskih integracija, br. 4., 2009., str. 108.

14 Loc. cit.

15 Vlahović, N., Jelić, B., op. cit., str. 65. 
detalje i specifičnosti svake od tih vrsta, bitno je ipak napomenuti kako se lobiranje javnih politika odnosi ponajprije na resore državne vlasti, kao što su, primjerice, gospodarstvo ili socijalna politika, dok se prostorno-plansko lobiranje odnosi na lobiranje na lokalnoj razini, odnosno jedinica lokalne i područne samouprave. Zakonodavno lobiranje, s druge strane, smatra se „tipičnim oblikom lobiranja, odnosno vrstom lobiranja s kojom se cjelokupna lobistička djelatnost najučestalije povezuje ${ }^{4}{ }^{16}$ a na javnu se nabavu, u pravilu, primjenjuju posebni propisi. ${ }^{17}$

Lobiranje može biti izravno i neizravno. Direktno ili izravno lobiranje podrazumijeva izravne sastanke s osobama iz onih tijela na koje se pokušava utjecati te pružanje dovoljno informacija kako bi ih se uvjerilo u donošenje one odluke koju se pokušava izlobirati. ${ }^{18}$ Razlika između izravnog i neizravnog lobiranja je da „neizravno lobiranje učestalo koristi tehnike izravnog lobiranja, međutim situacija nije obostrana." ${ }^{19}$ Naime, neizravno se lobiranje naziva i grassroots budući da „u postupku utjecaja koristi posrednike (građane, birače, koalicije, tvorce javnog mnijenja, medije, udruge), u svrhu aktiviranja većeg kolektiva koji je u mogućnosti

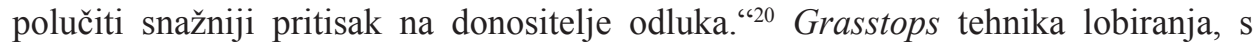
druge strane, mobilizira prominentne članove zajednice, određenu elitu. Cilj je takvog lobiranja ,shvatiti kome pojedini član Kongresa ne može reći 'ne' (npr. ključni donator)“ pa se lobiranje usmjerava prema toj osobi ,iznad“ samog zakonodavca, ne bi li se „odozgo“" utjecalo na donošenje odluke. ${ }^{21}$ Ovdje valja spomenuti i pojam astroturf kojim se označava „,umjetnu lobističku tehniku koja nastoji preslikati tipičnu grassroots kampanju koristeći frizirane i izmišljene informacije (na primjer, slanje izmišljenih pisama)."222 Zanimljivo je istaknuti da sam pojam astroturf nosi naziv prema proizvođaču tepiha umjetne trave, upravo kako bi se označilo lažnu grassroots tehniku.

Razlikovanje tipova lobista ovisi o organizacijama unutar kojih oni djeluju. VlahovićiJelićističukakosunajčešćitipovi:„,korporativnilobisti,lobistiuasocijacijama, lobisti u konzultantskim tvrtkama, lobisti u nevladinim organizacijama." ${ }^{23}$ Postoje i druge podjele koje uključuju, primjerice, i izvaninstitucijsko lobiranje za socijalne ili ekološke pokrete. Sudeći prema nalazu Venecijanske komisije, u literaturi prevladava mišljenje da takve lobističke ili interesne skupine ili izvaninstitucijski subjekti mogu uključivati, ali nisu nužno ograničeni samo na one subjekte s ekonomskim i profesionalnim interesom te interesom civilnoga društva. ${ }^{24}$

Moguće je govoriti i o lobijima vezujući ih uz konkretne djelatnosti, što je

16 ibid., str. 68.

17 Kao što je poznato, primjerice u RH, Zakon o javnoj nabavi, NN br. 120/16.

18 The Princeton Review - Lobbyist, dostupno na: https://www.princetonreview.com/careers/88/ lobbyist, posjećeno 11.06.2017.

19 Vlahović, N., Jelić, B., op. cit., str. 103.

20 Ibid., str. 174.

21 Davidson, Roger H., Oleszek, Walter J., Lee, Frances E., Congress and Its Members, CQ Press, Washington, 2012., str. 385.

22 Vlahović, N., Jelić, B., op. cit., str. 173.

23 Ibid., str. 73.

24 prema: European Commission for Democracy through Law (Venice Commission): Report..., op. cit., str. 3 . 
vjerojatno široj javnosti i najpoznatija fraza, pa se tako danas nerijetko izdvajaju farmaceutski, naftni, automobilski ili bankarski lobi. Neminovno se nameće i pitanje kome su potrebne usluge lobista, odnosno tko ih angažira. Prema Vlahoviću i Jeliću ${ }^{25}$ to su kompanije, sindikati, strukovna udruženja i komore te nevladine organizacije.

Lobisti su vrlo različitih struka, odnosno profesija, a većina ima završen fakultet i to najčešće ekonomiju, pravo, novinarstvo, komunikologiju, politologiju ili, još uže, odnose s javnošću. ${ }^{26}$ Za lobiste su važna i mnogobrojna poznanstva, ${ }^{27}$ liderstvo, vještine pregovaranja, uvjeravanja, analitička moć, a nezaobilazno je temeljito razumijevanje zakonodavnog procesa te procesa potrebnih za donošenje drugih akata.

\section{RAZVOJ REGULACIJE LOBIRANJA U SJEDINJENIM AMERIČKIM DR ŽAVAMA}

\subsection{Početci lobiranja u Sjedinjenim Američkim Državama}

Sjedinjene Američke Države zemlja su s daleko najrazvijenijim sustavom lobiranja u komparativnoj analizi sa zemljama članicama Europske unije, ali i Bruxellesom. Prema jednoj teoriji, pojam „lobi“ skovao je sredinom 19. stoljeća Ulysses S. Grant kako bi opisao političare ili trgovačke putnike koji su se skupljali u predvorju hotela (lobby) kako bi mu prišli te pokušali iznijeti svoja stajališta, odnosno utjecati na njega. Međutim, neki izvori bilježe i raniji početak lobiranja koji se veže uz 1792. godinu i ime Williama Hulla, jednog od prvih poznatijih lobista u Sjedinjenim Američkim Državama, kojeg su angažirali veterani kontinentalne armije države Virginije kako bi lobirao za dodatna prava i novčane naknade zbog njihovih doprinosa u ratu. ${ }^{28}$

Krajem devetnaestog stoljeća, točnije 1875 . godine, zbio se poznati skandal vezan uz Sama Warda, „kralja“ lobija (King of the Lobby). ${ }^{29}$ Naime, Ward je bio osebujna ličnost čije djelovanje obuhvaća razdoblje u vrijeme i nakon američkog Građanskoga rata (Civil War). Prema njegovim riječima, shvatio je da „najkraća udaljenost između zakona koji treba izglasati i kongresmenovog pristanka (aye) leži u bogatim večerama i prvoklasnim vinima" ${ }^{30} \mathrm{U}$ tu je svrhu, utvrđeno je, potrošio preko 12.000 tadašnjih američkih dolara. Ward je radio za brojne klijente, privatnike i pojedince te je dugi niz godina uspio izbjeći afere, sve dok 1875. godine nije bio pozvan svjedočiti o podmićivanju brojnih dužnosnika. Inače, najutjecajniji lobiji toga vremena radili su na pitanjima subvencija i carina za vunu, dok je u južnim državama Sjedinjenih Američkih Država lobiranje bilo često povezano uz prometnu

25 Vlahović, N., Jelić, B., op. cit., str. 75-81.

26 Princeton Review, Lobbyist, op. cit.

27 Osredečki, E., op. cit., str. 103.

28 United States Senate, Legislation and Records, Lobbying, dostupno na: https://www.senate. gov/legislative/common/briefing/Byrd_History_Lobbying.htm, posjećeno 11.06.2017.

29 Bloomberg Business, A Brief History of Lobbying, dostupno na: https://www.bloomberg.com/news/articles/2012-06-07/a-brief-history-of-lobbying, posjećeno 11.06.2017.

30 United States Senate, Legislation..., op. cit. 
infrastrukturu (željeznice), ali i igre na sreću (kockarnice). ${ }^{31}$

\subsection{Foreign Agents Registration Act (FARA) 1938.}

Prvi sveobuhvatniji pokušaj reguliranja lobiranja na federalnoj razini bio je Zakon o registraciji stranih agenata (Foreign Agents Registration Act $-F A R A)^{32}$ iz 1938. godine. Prema tom zakonu, „savjetnici koji služe stranim vladama moraju se registrirati, bez obzira jesu li lobisti ili ne“".33 Svrha ovoga zakona bila je ponajprije ograničiti utjecaj stranih agenata te nacističke i fašističke propagande u Sjedinjenim Američkim Državama. Iako nisu postojali čvrsti dokazi, brojni članovi Kongresa, kao i predsjednik Franklin D. Roosevelt, smatrali su da Hitler pomaže financirati nacistički pokret u Sjedinjenim Američkim Državama. ${ }^{34}$

Donošenje ovog zakona treba sagledati kroz prizmu događaja koji su mu prethodili. Naime, već dvadesetih godina prošlog stoljeća dolazi do promjena i u tehnikama lobiranja i u sredstvima lobiranja, osobito zbog pojave telegrafa, telefona $\mathrm{i}$ radija, koji su intenzivirali razvoj grassroots lobiranja. ${ }^{35}$ Senat je 1928. godine odredio da se lobisti moraju registrirati kako bi mogli lobirati. Daljnji poticaj donošenju FARA-e bio je još jedan skandal koji je potresao Sjedinjene Američke Države onoga doba. Otkriveno je da je senator Connecticuta Bingham stavio na platnu listu Senata Charlesa Eyansona, lobista za udruženje proizvođača Connecticuta, a koji je sudjelovao, zajedno sa senatorom, na zatvorenim sjednicama Odbora za financije Senata. Senat je nakon provedene istrage osudio njegovo djelo kao postupanje protivno moralu i senatorskoj etici.

Početkom tridesetih godina nastavljene su istrage o lobiranju, a jedan od istražitelja koji se u njima isticao bio je senator Hugo Black iz Alabame. On je postupno gradio i naposljetku uživao ugled ustrajnog i nadarenog istražitelja Kongresa, koji se stalno zalagao da lobisti javno registriraju svoja imena, ciljeve, plaće i mjesečne troškove. Njegova su se nastojanja i ostvarila kada je Public Utilities Holding Company Act izmijenjen na način da se traži registracija svih agenata kompanije. Kongres je bio voljan i regulirati lobiranje po granama industrije, pa su tako već 1936. godine uvedene odredbe o registraciji u Merchant Marine Act, a uskoro je donesen i Foreign Agents Registration Act (FARA). ${ }^{36}$

Prema Zakonu o registraciji stranih agenata, agentom se smatrala svaka osoba „koja djeluje kao lobist, savjetnik za odnose s javnošću ili odvjetnik za strano predstavništvo ili bilo koju domaću organizaciju koju financira strana kompanija“". ${ }^{37}$

31 Vidi detaljnije Vlahović, N., Jelić, B., op. cit., str. 22.

32 Foreign Agents Registration Act, dostupno na: https://www.fara.gov/indx-act.html, posjećeno 12.06.2017.

33 Cutlip, Scott M., et al., op. cit., str. 191.

34 Holman, Craig, Making the U.S. Lobbying Disclosure Act Work as Intended: Implications for the European Transparency Initiative, Public Citizen, 2007., dostupno na: https://www.citizen. org/sites/default/files/making-lda-work.pdf, str. 2.

35 United States Senate, Legislation..., op. cit.

36 loc.cit.

37 Holman, Craig, Origins, Evolution and Structure of the Lobbying Disclosure Act, Public 
Strano se predstavništvo odnosilo na „stranu vladu, političku stranku, korporaciju, entitet ili pojedinca osnovanu po pravu strane zemlje ili koje ima središnje mjesto poslovanja u stranoj državi.“38 Entitet osnovan po američkom pravu nije strano predstavništvo, ali ako je ono u vlasništvu ili ga kontrolira strani entitet te aktivnosti koje poduzima idu u korist stranom entitetu, tada je moguće zahtijevati registraciju po FARA-i. Međutim, zakon se ipak nije odnosio na sve djelatnosti koje odgovaraju opisanim kriterijima, pa su tako iz njega izuzete i privatne i nepolitičke aktivnosti koje bona fide obavlja takvo strano predstavništvo u komercijalnom, trgovačkom smislu ${ }^{39}$ te ,diplomati, službenici stranih vlada, novinari koji rade za američke publikacije i osobe koje se bave dobrotvornim ili vjerskim djelatnostima." ${ }^{\text {"40 }}$ Registraciju je bilo potrebno izvršiti u roku od deset dana od zapošljavanja, koristeći obrazac za registraciju, a bitno je istaknuti kako po FARA-i ne postoji pravilo de minimis - zahtjev za registraciju postoji čak i ako je riječ o radu koji je pro bono. ${ }^{41}$

FARA je izmijenjen kasnijim, Lobbying Disclosure Actom iz 1995. godine. Ova su se dva zakona međusobno isključivala u pogledu registracije, pa ako je pojedinac bio registriran sukladno odredbama jednoga zakona, nije se morao opet registrirati po odredbama drugoga, no odluka o tomu nije bila isključivo u njegovim rukama. Naime, ako je riječ o lobiranju na zahtjev stranog predstavništva, a namjera lobiranja odnosi se na američku vladu ili bilo koji dio politike Sjedinjenih Američkih Država $\mathrm{u}$ odnosu na strane države, tada je izbor ograničen na registraciju sukladno Zakonu o registraciji stranih agenata, odnosno FARA-i. ${ }^{42}$

\subsection{Federal Regulation of Lobbying Act (FRLA), 1946.}

Nakon turbulentnih vremena Drugog svjetskog rata godine 1946. Kongres donosi Zakon o saveznom reguliranju lobiranja, odnosno Federal Regulation of Lobbying Act (FRLA). Taj je zakon činio treću glavu Zakona o reorganizaciji zakonodavstva $^{43}$ (Legislative Reorganization Act), također iz 1946. godine. Riječ je o prvoj tako opsežnoj regulaciji domaćeg lobiranja, kojom se nastojalo obznaniti javnosti političke pritiske na zakonodavstvo. Ujedno, Zakon o saveznom reguliranju lobiranja imao je za cilj „ustanoviti sustav registracije i obznanjivanja lobista javnosti te nije, kao ni FARA, imao za cilj regulaciju aktivnosti lobiranja ili ograničavanja njihovih financijskih aktivnosti."“44Taj je zakon, međutim, dao opsežnu definiciju lobista smatrajući lobistom „svaku osobu koja sama ili posredstvom nekog agenta ili

Citizen, 2006., dostupno na: http://www.consumerwatch.org/documents/Origins $\% 20$ of $\% 20$ Lobbying\%20Disclosure\%20Act.pdf, str. 4.

Loc. cit.

39 Political Law Blog, What is the Foreign Agents Registration Act (FARA)?, dostupno na: https://www.hklaw.com/politicallawblog/what-is-the-foreign-agents-registration-actfara-06-01-2016/, posjećeno 10.07.2017.

40 Cutlip Scott M., et al., op. cit., str. 191.

41 Political Law Blog, What is the Foreign Agents Registration Act (FARA)?, op. cit.

42 Loc. cit.

43 United States Senate, Legislation..., op. cit.

44 Holman, C., Making the U.S. Lobbying Disclosure Act..., op. cit., str. 3. 
zaposlenika ili trećih osoba na bilo koji način, izravno ili neizravno traži, prikuplja ili prima novac ili bilo koju drugu vrijednost koje će se primarno koristiti radi utjecaja, izravnog ili neizravnog na donošenje ili nedonošenje bilo kojeg zakonodavnog akta Kongresa Sjedinjenih Američkih Država." "45 Svaka osoba koja je odgovarala danom opisu morala se registrirati te dati podatke o adresi, plaći i troškovima tajniku Senata ili ovlaštenom činovniku, kao i podnositi kvartalna izvješća „o novcu potrošenom na lobiranje te o izvorima prihoda. “46 Također, bilo je potrebno izvijestiti i o tomu ,kome su i u koje svrhe" ta sredstva isplaćena, pa čak i imena dnevnih novina i magazina u kojima su objavljeni članci ili uvodnici upravo pod utjecajem lobista, kao i koji su to zakoni na koje su lobisti trebali utjecati u cilju njihova donošenja, odnosno nedonošenja. ${ }^{47} \mathrm{U}$ slučaju nepoštovanja ovih odredbi bile su predviđene kaznenopravne sankcije u visini od pet tisuća dolara ili godine dana zatvora i trogodišnjom zabranom obavljanja lobističkih djelatnosti. ${ }^{48}$

Istovremeno, Zakon o saveznom reguliranju lobiranja imao je brojne propuste i poroznosti koje su dovele do znatne neučinkovitosti i ponovno ukazale na potrebu drukčijeg, zapravo striktnijeg reguliranja pravnog položaja lobista toga doba. Analizirajući učinak Zakona o saveznom reguliranju lobiranja, američki General Accounting Office (GAO), odnosno Ured za opće računovodstvo, u svojoj studiji iz 1991. godine, konstatira kako čak 10.000 od 13.500 osoba navedenih u popisu pod nazivom Directory of Washington Representatives, a koji je sadržavao popis osoba i organizacija od ključnog interesa na Capitol Hillu, nije bilo prijavljeno kao lobisti sukladno odredbama spomenutog Zakona. Od prijavljenih, čak preko $60 \%$ nije uopće podnijelo izvješća o financijskoj aktivnosti, $90 \%$ nije prijavilo plaće, naknade ili provizije, a $95 \%$ nikakve odnose s javnošću ili izdatke za oglašavanje. ${ }^{49}$ Tijekom gotovo polovice stoljeća koliko je predmetni zakon bio na snazi, samo su dvojica lobista bila temeljem njega optužena i kažnjena. ${ }^{50}$ Nadalje, Zakon o saveznom reguliranju lobiranja nije obuhvaćao ni neke od ključnih osoba u procesu lobiranja, a to su primjerice osoblje u Kongresu ili članovi izvršne vlasti, kao ni grassroots lobiranje. U presudi U.S. v. Harriss ${ }^{51}$ 1954. godine, Vrhovni je sud dodatno suzio polje primjene ovog zakona nalazeći da se on ne primjenjuje na osobe ili organizacije koje koriste vlastiti novac kako bi izravno lobirali u Kongresu, ${ }^{52}$ kao i konstatirajući činjenicu da je namjera Kongresa bila obznaniti javnosti samo izravnu komunikaciju s članovima Kongresa glede federalnog zakonodavstva, a ne i grassroots lobiranje. ${ }^{53}$ Takav pravorijek Craig Holman smatra svojevrsnim kompromisom, kojeg je Vrhovni

45 United States Senate, Legislation..., op. cit.

46 Cutlip, Scott M., et al., op. cit., str. 189.

47 United States Senate, Legislation..., op. cit.

48 Holman, C., Making the U.S. Lobbying Disclosure Act..., op. cit., str. 3.

49 Holman, Craig, Lobbying Reform in the United States and the European Union:

Progress on Two Continents, Public Citizen, dostuspno na: https:/www.citizen.org/sites/ default/files/lobbying-reform-in-the-us-eu.pdf, posjećeno 12.06.2017., str. 6.

50 United States Senate, Legislation..., op. cit.

51 United States v. Harriss, 347 U.S. 612 (1954).

52 United States Senate, Legislation..., op. cit.

53 Maurer, William R., The Regulation of Grassroots Lobbying, Engage, vol. 11., br. 1., str. 74. 
sud izveo ne bi li ipak održao na snazi ovaj Zakon, jer ga je i zbog objektivnih propusta u samom tekstu zakona i zbog uvriježenog (iako manjkavog) tumačenja njegovih odredbi u praksi relevantnih državnih tijela, bilo moguće i u potpunosti ukinuti. ${ }^{54}$

\subsection{Lobbying Disclosure Act (LDA) 1995.}

Motivacija za novu zakonodavnu intervenciju krajem 20. stoljeća bila je dvojaka. Uz već gore spomenute probleme i ograničenje smisla FRLAe te de facto neprimjenu velikog dijela njegovih odredbi, valja istaknuti stalni pritisak američke javnosti koji nije jenjavao zbog brojnih skandala vezanih za istaknutije pripadnike lobističke djelatnosti. Naime, Sjedinjene Američke Države sedamdesetih godina trese afera Watergate, rezultirajući ostavkom predsjednika Nixona, a malo zatim i Koreagate u koji je umiješan „azijski veliki Gatsby“, Tongsun Park, južnokorejski lobist. U tim okolnostima jačaju zahtjevi javnosti za regulacijom pitanja lobiranja, pa tako Senat 1976. donosi „konkretnije definicije lobiranja i lobista, "55 no one zbog vapaja samih lobista ne prolaze u Kongresu, budući da su lobisti tvrdili kako bi nova pravila ugrozila njihovo pravo na slobodu govora. Početkom devedesetih godina na pomolu je nova afera, Wedtech, u koju je umiješano „mnogo lobista, uključujući i bivše članove Kongresa“" 56 te su sklopljeni lukrativni ugovori bez prijavljivanja lobističke aktivnosti. Kasnija istraga predmetnog slučaja ukazala je na mnoge propuste u pravnoj regulaciji lobiranja te je Kongres morao što hitnije reagirati kako bi „osvjetlao obraz“ i ublažio pritiske koji su dolazili sa svih strana. Napori su u konačnici urodili plodom, 19. prosinca 1995. godine, Bill Clinton potpisuje Zakon o objavljivanju lobističke djelatnosti (Lobbying Disclosure Act - LDA), koji stupa na snagu 1. siječnja 1996. godine. $^{57}$

Predmetni zakon zamjenjuje i objedinjuje i Zakon o registraciji stranih agenata $(F A R A)$ i Zakon o saveznom reguliranju lobiranja (FRLA), kao i amandmane senatora Roberta Byrda, ${ }^{58}$ dajući nove definicije prijelomnih točaka - pojmove lobista, lobističke tvrtke te lobističkog doticaja. Opetovano je riječ o problematici definiranja određenih pojmova u lobiranju, a njihovu važnost potvrđuje i mišljenje Odbora

54 Uz spomenute nedostatke neobuhvaćanja Kongresnog osoblja i neprotezanja na izvršnu vlast te neobuhvaćanje grassroots lobiranja, predmetni propis nije zahtijevao od aktera lobiranja da obznane javnosti ključne podatke: podatke o ukupnim troškovima i njihovoj cjelokupnoj svrsi, a bilo je i nejasno kome je sve lobiranje primarna djelatnost i tko bi se shodno tomu trebao registrirati kao lobist. Prema tumačenju i praksi Ministarstva pravosuđa (Department of Justice) bilo je očito da smatraju ispravnim potencijalne prijestupnike navesti na registraciju, ne smatrajući svrhom Zakona njihovo privođenje pravdi i kažnjavanje zbog kršenja propisa. Isto tako, i ostale institucije nadležne za provođenje ovog zakona smatrale su se više depozitorijem informacija, ne prihvaćajući ulogu ukazivanja na eventualne pogreške, odnosno ne mareći za dosljedno provođenje slova zakona. Holman, C., Making the U.S. Lobbying Disclosure Act..., op. cit., str. 4.

55 United States Senate, Legislation..., op. cit.

56 Holman, C., Origins, Evolution and Structure of the Lobbying Disclosure Act, op. cit., str. 8.

57 Lobbying Disclosure Act, dostupno na: https://lobbyingdisclosure.house.gov/lda.html, posjećeno 13.06.2017.

58 Holman, C., Origins, Evolution and Structure of the Lobbying Disclosure Act, op. cit., str. 6. 
Senata za gospodarska pitanja u kojem se navodi da su ,jasne definicije krucijalne za učinkovit režim objavljivanja. “59 Prema novom Zakonu, lobist je „,netko koga je klijent zaposlio ili angažirao, netko tko je ostvario više od jednog kontakta u ime klijenta te tijekom šestomjesečnog razdoblja proveo barem dvadeset posto svoga vremena služeći klijentu na navedeni način."“60 Široko definiranje lobista uvedeno kako bi se svako ,pripremanje ili nadziranje aktivnosti za lobistički kontakt smatralo jednakim samom lobističkom kontaktu." ${ }^{61}$ Uvedeno je i razlikovanje dviju vrsta lobista: inhouse lobisti promoviraju interese organizacije koja ih zapošljava i posla vezanog uza nj, dok su outside lobisti na ugovornoj osnovi povezani s klijentom izvan njihove organizacije ili posla. ${ }^{62}$ Nadalje, lobističkom tvrtkom smatra se „entitet s barem jednom osobom koja je angažirana da predstavlja nekoga tko nije njen poslodavac. Termin se odnosi i na samozaposlene pojedince koji predstavljaju druge osobe ili entitete.“63 I, konačno, lobistički doticaj definira se kao „komunikacija (usmena ili pismena) u ime klijenta s odabranim predstavnikom izvršne ili zakonodavne vlasti, a vezano uz donošenje zakona, propisa, davanje dotacija, zajmova, dozvola, usvajanje programa ili nominiranja nekoga čije imenovanje potvrđuje Senat."64 Uvođenjem ovoga zakona proširuje se pojam covered officials (osobe koje su zakonom određene kao kreatori politika ili savjetnici) ${ }^{65}$ pa on više ne obuhvaća samo članove Kongresa, već i kongresno osoblje (svi djelatnici Kongresa) te izabrane dužnosnike, kao i osoblje izvršne vlasti. ${ }^{66}$

Pravne posljedice Zakona o objavljivanju lobističke djelatnosti $(L D A)$ su ponajprije vezane za promjene u prethodno navedenim definicijama, pa se tako uvodi i prag kada se lobiranje mora registrirati. Naime, pojedinac ili organizacija čiji kombinirani troškovi za lobističke aktivnosti ne prelaze de minimis iznos $\mathrm{u}$ šestomjesečnom razdoblju, ne moraju se, prema $L D A$, registrirati. Za in-house lobiste prag koji aktivira registraciju je 22.500 USD u ukupnim lobističkim aktivnostima. Lobističko trgovačko društvo, uključujući i samozaposlene lobiste, ne treba registrirati lobiranje u ime bilo kojeg klijenta ako klijent plati tvrtki ili lobistu manje od 5.000 USD. Nakon što se dosegne de minimis iznos, „,svaka osoba, koja je zaposlenik organizacije koja se bavi lobiranjem ili koja radi za lobističku kompaniju ili je samozaposlena ili koja za klijenta obavlja lobističke aktivnosti, mora registrirati lobističke prihode i rashode ako primi znatnu kompenzaciju, stvori više od jednog lobističkog kontakta u šestogodišnjem razdoblju te provede najmanje $20 \%$ svoga vremena baveći se lobističkim djelatnostima na zahtjev svakog pojedinog klijenta, a koje uključuju i

59 Holman, C., Making the U.S. Lobbying Disclosure Act..., op. cit., str. 6.

60 Cutlip, Scott M., et al., op. cit., str. 189.

61 Holman, C., Origins, Evolution and Structure of the Lobbying Disclosure Act, op. cit., str. 9.

62 Holman, C., Making the U.S. Lobbying Disclosure Act..., op. cit., str. 7 i https:// lobbyingdisclosure.house.gov/amended_lda_guide.html, posjećeno 12.06.2017.

63 Cutlip Scott M., et al., op. cit., str. 189.

64 Loc. cit.

65 Open Secrets Org., Center for Responsive Politics, Glossary, dostupno na: https://www.opensecrets.org/lobby/lobby00/glossary.php, posjećeno 12.06.2017.

66 Holman, C., Origins, Evolution and Structure of the Lobbying Disclosure Act, op. cit., str. 9. 
istraživanje, pripremanje te nadzor lobističkih kontakata“ ${ }^{67}$ Konstrukcija „,za svakog pojedinog klijenta“ zapravo rješava tzv. „odvjetnički problem.“ Naime, velik broj odvjetnika bavi se i lobiranjem. Kada prijeđu prag od $20 \%$ za svakog pojedinog klijenta, odvjetnici koji su angažirani za lobiranje na zahtjev određenoga klijenta obvezni su registrirati se i otkrivati dotični posao vezan uz lobiranje, dok se ostali poslovi koji nisu povezani s lobiranjem ne registriraju i ne obznanjuju, budući da bi se time prekršila obveza čuvanja odvjetničke tajne (zakletva o privatnosti koju odvjetnici moraju dati svojim klijentima) ${ }^{68}$

Prema $L D A$, lobisti su obvezni podnositi financijska izvješća dva puta godišnje - za razdoblje od 1. siječnja do 30. lipnja te od 1. srpnja do 31. prosinca. Izvješća moraju sadržavati i procjene „, dobroj vjeri, o iznosima koje su dobili od klijenata ili potrošili na lobiranje. “69 Ipak, samo objavljivanje izvješća nije prošlo bez problema. Naime, iako je Kongres shvaćao važnost objavljivanja javnosti dotičnih informacija o lobiranju, treba uzeti u obzir da je riječ o tisućama i tisućama registracija te da je riječ o doista ogromnom i zahtjevnom zadatku. Niti Ured Vlade za dobro upravljanje (Office of Governmental Ethics) niti Ministarstvo pravosuđa (Justice Department) nisu željeli preuzeti status agencije zadužene za prijavu lobista i objavljivanje podataka javnosti, pa je tu ulogu prvotno preuzela Savezna izborna komisija (Federal Election Commission) na temelju izjave njezinog ravnatelja Scotta Tomasa „da je izborna agencija relativno pripremljena za preuzimanje dužnosti objavljivanja sukladno Zakonu“". ${ }^{70}$ Kongres je potom, kao konačno rješenje, dodijelio tu obvezu Tajništvu Zastupničkog doma (Clerk of the House) i Ministarstvu vanjskih poslova (Secretary of the State). ${ }^{71}$ Od 1. siječnja 2017. godine na snagu stupaju amandmani Zakona o objavljivanju lobističke djelatnosti. Sukladno tomu, društvo koje se bavi lobiranjem, a čiji ukupni prihod vezan uz pojedinog klijenta ne prelazi (ili se ne očekuje da će prijeći) 3.000 USD u kvartalu, ne mora se registrirati u odnosu na toga klijenta. Ni društvo koje zapošljava in-house lobista, čiji ukupni troškovi vezani uz lobističke aktivnosti ne prelaze (i ne očekuje se da će prijeći) ukupan iznos od 13.000 USD u kvartalnom razdoblju, ne treba se registrirati. Nadalje, izmijenjena sekcija 4(a)(3) LDA predviđa promjene u novčanim pragovima koji zahtijevaju registraciju svake četiri godine, ovisno o promjenama u indeksu potrošačkih cijena (Consumer Price Index (CPI)) pa je sljedeća promjena predviđena za 1. siječnja 2021. godine. ${ }^{72}$ Ostale izmjene i dodatna pojašnjenja vezana su za klijente i „pokrivene dužnosnike“ (engl. covered officials), zaokruživanje prihoda i rashoda te izvješćivanje, vanjske lobiste,

67 Holman, C., Making the U.S. Lobbying Disclosure Act..., op. cit., str 8.

68 Holman, C., Lobbying Reform in the United States..., op. cit., str. 7.

69 Cutlip Scott M., et al., op. cit., str. 190.

70 Holman, C., Making the U.S. Lobbying Disclosure Act..., op. cit., str. 9.

71 Novosti vezane za obvezu registracije te objavljivanje podataka o lobiranju moguće je pratiti na službenoj stranici SOPR-a (Senate Office of Public Records): https://www.senate.gov/ legislative/opr.htm te na stranici: https://lobbyingdisclosure.house.gov/index.html, posjećeno 08. kolovoza 2017.

72 United States Senate, Registration Tresholds, dostupno na: https://www.senate.gov/legislative/Public_Disclosure/new_thresholds.htm, 09.11.2017.

posjećeno 
javnu dostupnost i usklađivanje itd. ${ }^{73}$

\subsection{Honest Leadership and Open Government Act (HLOGA), 2007.}

Uz određene manjkavosti u sadržaju i/ili primjeni $F R L A$-e i $L D A$-e sustav registracije i objavljivanja relevantnih podataka vezanih uz lobističku djelatnost ipak je zaživio u SAD-u (osobito vezano uz podatke tko plaća lobiste, koliko su plaćeni te za koje legislativne mjere ili vladine ugovore lobiraju). No, 2006. godine Sjedinjene Američke Države ponovno pogađa lobistički skandal, sada vezan uz Jacka Abramoffa. Radi se o odvjetniku s diplomom Sveučilišta Georgetown, koji je vrlo brzo postao jedan od najutjecajnijih lobista $\mathrm{u}$ Washingtonu. ${ }^{74}$ Protiv njega su podignute brojne optužnice, a primarno se teretio za prikupljanje milijuna dolara kroz napuhane lobističke kampanje te korištenje novca za utjecanje na kongresmene te druge osobe, uglavnom s pomoću darova i političkih donacija. ${ }^{75}$ Iste godine, Abramoff je optužen za utaju poreza, prijevaru te urotu povezanu s poslovima vezanima za kasino na Floridi te je osuđen na kaznu od pet godina i deset mjeseci u federalnom zatvoru. No, Abramoff pristaje otkriti istražiteljima potrebne informacije o svojim dogovorima s članovima Kongresa, pa je 2010. godine pušten iz zatvora te sljedeće godine objavljuje knjigu Capitol Punishment: The Hard Truth About Washington Corruption from America's Most Notorious Lobbyist ${ }^{76}$ a po njemu je snimljen i biografski film Casino Jack.

Bilo kako bilo, Abramoffljev slučaj ukazao je na brojne propuste te pojačao pritiske za dodatnom regulacijom određenih pitanja vezanih uz lobističku profesiju, pa je 2007. godine donesen Zakon o pristojnom i otvorenom upravljanju (Honest Leadership and Open Government Act (HLOGA)). ${ }^{77}$ Najvažnije novine koje su uvedene ovim zakonom odnose se ponajprije na regulaciju pitanja „ponašanja“ lobista. Važna novina je uvođenje online ispunjavanja lobističkih izvješća. ${ }^{78}$ Praksa prije ove izmjene uključivala je ispisivanje svih podataka, koji ionako već postoje u elektroničkom izdanju, da bi se potom oni iz papirnatoga prebacivali opet u elektroničko izdanje i

73 U.S. House of Representatives, Office of the Clerk, Lobbying Disclosure Act Guidance, dostupno na:

https://lobbyingdisclosure.house.gov/amended_lda_guide.html, posjećeno 08.11.2017.

74 Koliki je njegov utjecaj bio, dovoljno govori činjenica da je 2006. godine bilo preko četrnaest tisuća registriranih lobista i onih koji se aktivno bave lobističkom djelatnošću samo u Washingtonu, a upravo je on bio jedan od najmoćnijih. Podatak preuzet s mrežne stranice Centre for Responsive Politics koja prati navedene podatke, dostupno na: https://www.opensecrets. org/lobby/, posjećeno 13.06.2017.

75 Infoplease, Jack Abramoff, dostupno na: https:/www.infoplease.com/people/who2-biography/ jack-abramoff, posjećeno 13.06.2017.

76 Smith, R. Jeffrey, The Washington Post, In Jack Abramoff's memoir, 'Capitol Punishment,' an unrepentant reformer?, dostupno na:

https://www.washingtonpost.com/entertainment/books/in-jack-abramoffs-memoircapitol-punishment-an-unrepentant-reformer/2011/11/30/gIQAxZIpiO_story.html?utm_ term $=.04 \mathrm{~b} 14 \mathrm{cf5} \mathrm{dd} 4 \mathrm{c}$, posjećeno 13.06.2017.

77 Honest Leadership and Open Government Act, dostupno na: http://clerk.house.gov/public disc/PLAW-110publ81.txt, posjećeno 13.06.2017.

78 Holman, C., Origins, Evolution and Structure of the Lobbying Disclosure Act, str. 14-15. 
napokon objavljivali, što je cijeli proces učinilo znatno dugotrajnijim i kompliciranijim. Poboljšano je i omogućeno jednostavnije pretraživanje izvještaja, budući da je do tada pretraživanje bilo moguće jedino u slučaju potpuno i cjelovito napisanog naziva, dok u protivnom pretraga ne bi dala rezultate. Uvedena su i poboljšanja sustava u vidu mogućnosti korisnika da ureduje mogućnosti pretraživanja, kao i da pohrani dokument na svoje računalo. Jedan od većih zahvata u proces objavljivanja i prijavljivanja informacija svakako je i novina po kojoj se izvješća podnose kvartalno, dakle četiri puta godišnje, za razliku od prethodnih polugodišnjih izvješća. Drugim riječima, HLOGA „nije težila povećanju broja osoba koje se registriraju kao lobisti na način da dodatno proširi definicije u odnosu na $L D A^{“},{ }^{79}$ već je njome povećana učestalost objave informacija.

Iako je i dalje dopušteno da lobisti prikupljaju sredstva za kampanje svojih klijenata, sada su dužni objavljivati podatke na internetu svakih šest mjeseci. Nije zanemariva ni izmjena prema kojoj se uvodi zabrana korištenja darova u zamjenu za osiguravanje određenih usluga ili ponašanja onih prema kojima je usmjerena lobistička djelatnost. Darivanje spomenutih osoba poprimilo je goleme razmjere, a jedan od okidača takve promjene bio je i ranije spomenuti slučaj Jacka Abramoffa. ${ }^{80}$ Jedina su iznimka darovi malene ili zanemarive vrijednosti, kao što su ,šalica kave ili domjenak na nekim događanjima, ako su jednake vrijednosti kao oni koji se pružaju

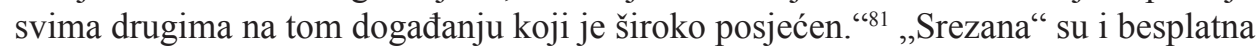
putovanja su u velikoj mjeri: dopušteni su samo jednodnevni izleti, odnosno koliko je potrebno da član Kongresa zrakoplovom stigne na konferenciju kako bi održao govor, a dvodnevni izleti su iznimka i dopušteni jedino ako to zahtijeva udaljenost odredišta. ${ }^{82}$ Jedna od važnijih novina poznata je pod sintagmom slowing the revolving door. Radi se o praksi prema kojoj se članovi Kongresa, koji idu u mirovinu, ,zavrte kroz rotirajuća vrata" te postaju lobistima, a nerijetko ih već prije umirovljenja čeka obećani lukrativni posao.$^{83}$ Stoga zakon bivšim kongresmenima te višim izvršnim dužnosnicima zabranjuje lobiranje njihovih kolega dvije godine nakon što napuste ured.

79 Straus, Jacob R., The Lobbying Disclosure Act at 20: Analysis and Issues for Congress, Congressional Research Service, 2015., str. 12. i 13., dostupno na: https://fas.org/sgp/crs/misc/ R44292.pdf, posjećeno 13.06.2017.

80 Darovi su se sastojali od najboljih sjedala na Super Bowlu, preko ručkova i večera unajprestižnijim restoranima, pa sve do besplatnih avionskih letova tijekom kojih bi lobisti osigurali nesmetano vrijeme s kongresmenom. Holman, C., Making the U.S. Lobbying Disclosure Act..., op. cit., str. 12.

81 Holman, C., Making the U.S. Lobbying Disclosure Act..., op. cit., str. 13.

82 Loc. cit.

83 Chomsky je fenomen ,rotirajućih ili kružnih vrata“ opisao jednostavno: „Prvo donosiš zakone pa onda postaneš lobist, a onda kao lobist želiš kontrolirati zakonodavstvo." Chomsky, Noam, Rekvijem za američki san: deset principa koncentracije bogatstva i moći, Sandorf, Zagreb, 2017., str. 81. 


\section{POGLED NA SUVREMENO LOBIRANJE U SAD-U I LJUDSKA PRAVA}

\subsection{Lobiranje u suvremenoj zbilji Sjedinjenih Američkih Država}

Razvidno je da su Sjedinjene Američke Države zemlja s najdužim kontinuitetom pravne regulacije lobiranja i zemlja koja stalno nastoji unaprijediti zakonodavstvo u tom području te povećati transparentnost lobiranja. Istovremeno je nemoguće ne primijetiti koliko je skandala i afera, snažno medijski popraćenih, služilo kao poticaj donošenju svakoga sljedećeg pravnog akta. Kakva je, dakle situacija danas, odnosno koji je sadržaj de lege lata regulacije i kakvi su njezini odjeci u praksi?

Danas se ,pojedinac mora registrirati kao savezni lobist ukoliko napravi dva ili više lobističkih kontakata s Kongresom ili izvršnom vlašću i provede najmanje $20 \%$ svoga vremena tijekom bilo koje kalendarske četvrti bavljenjem s lobističkim aktivnostima za naknadu veću od 2.500 USD (tj. 3.000 USD u slučaju inflacije) od jednoga klijenta. ${ }^{\text {(84 }}$ Registrirani lobist dužan je detaljno prijavljivati svaka tri mjeseca podatke o lobističkim aktivnostima te iznosu naknade od 10.000 USD. U praksi se pak pojavljuju dva glavna problema.

Prvi problem proizlazi iz činjenice da je prag od $20 \%$ istovremeno previsok, ali i zapravo neprimjenjiv. Gotovo je nemoguće da itko osim osobe koja je uključena u lobističku djelatnost raspolaže preciznim podatkom o točnom iznosu pruženih usluga. Prostor za manipulacije je velik, a mogućnosti nadzora vrlo male. I, drugo, prema trenutačnim zahtjevima za objavljivanjem, nije potrebno navoditi imena osoba koje su „iza scene“, odnosno osoba koje pružaju bitnu potporu lobiranju kroz strateško planiranje, odnose s javnošću ili operacije vezane uz glasovanje. Stoga ne čudi da ovo zakonsko rješenje dovodi do pojave sivog područja u kojem se brojni pojedinci ističu u djelatnostima vrlo povezanima s lobiranjem, iako se nikada nisu registrirali kao lobisti. Takav je slučaj, primjerice, bivšeg speakera Zastupničkog doma Newta Gingricha, koji ističe da je radio kao „strateški savjetnik od 2001. do 2010. godine za različite skupine" te tvrdi kako se nikada nije bavio lobiranjem, unatoč tomu što je, prema navodima dnevnih novina The Washington Post i The New York Times, ${ }^{85}$ dogovarao sastanke kompanija i izabranih dužnosnika. Slične se situacije vežu i uz brojna druga imena. ${ }^{86}$

U recentnijoj političkoj zbilji Sjedinjenih Američkih Država pitanje regulacije lobiranja i zatvaranja „rotirajućih vrata“ bilo je sastavni dio predizbornih obećanja predsjednika Baracka Obame, što se kasnije u američkoj javnosti percipiralo kao

84 The Campaign Legal Center, The Failure of the Lobbying Disclosure Act (LDA) and Proposed Reforms, Washington DC, dostupno na:

http://www.campaignlegalcenter.org/sites/default/files/LDA $\% 20$ Fact $\% 20$ Sheet $\% 20$ FINAL\%207-28-15.pdf, posjećeno 13.06.2017., str. 2.

85 Ibid., str. 3.

86 Vidjeti više na:

http://www.campaignlegalcenter.org/sites/default/files/LDA $\% 20$ Fact $\% 20$ Sheet $\% 20$ FINAL\%207-28-15.pdf, posjećeno 13.06.2017. 
neuspješno, ${ }^{87}$ dok su lobisti s $K$ Streeta, sinonima za lobiranje u Washingtonu, smatrali da je kontradiktorno onemogućiti najuspješnijim pojedincima zapošljavanje na tako važnim poslovima. ${ }^{88}$ Riječ je o tzv. periodu hlađenja (engl. cooling-off period), odnosno o razdoblju u kojem bivši „legislator“ ne može raditi kao lobist zbog vrlo realne opasnosti od sukoba javnog i privatnog interesa. Određivanje takvog razdoblja prisutno je u najmanje 34 američke države" ", 89 iako sama duljina trajanja ,perioda hlađenja“ varira od države do države. Praksa, pak pokazuje ozbiljne nedostatke, odnosno neprimjenu i/ili svakovrsno zaobilaženje smisla i sadržaja takvih ograničenja. ${ }^{90}$

Prema službenom priopćenju Bijele kuće od 27. travnja 2017. godine, predsjednik Trump uveo je nove etičke standarde, „kako bi osigurao da njegova administracija služi američkom narodu, a ne privatnim interesima“, pa je tako „uveo nove lobističke standarde za političke dužnosnike, uključujući petogodišnju zabranu lobiranja i doživotnu zabranu lobiranja za strane države. ${ }^{“ 91}$ Međutim, Craig Holman, vrstan poznavatelj ove tematike, a potaknut okolnostima da je bivši lobist za kompanije za područja nafte i plina sada savjetnik za energetiku Bijele kuće te da je bivši lobist na području graditeljstva sada zaposlen u Ministarstvu rada, tvrdi kako se lobist zapravo može ,deregistrirati u ponedjeljak i ući u Trumpovu administraciju u utorak““.92 Među zadnjim vijestima na području lobiranja u Sjedinjenim Američkim Državama je i ,zaokret“ nekih od važnih lobista Demokratske stranke još iz doba predsjednika Clintona, koji sada surađuju s republikanskom, Trumpovom administracijom, ${ }^{93}$ kao i novosti vezane uz Jacka Abramoffa koji je, navodno, bio uključen u pokušaj

87 Vidi, primjerice: Politico, Revolving Door, dostupno na: http://www.politico.com/story/2015/12/ barack-obama-revolving-door-lobbying-217042, posjećeno 14.06.2017.

88 Loc.cit.

89 National Conference of State Legislature, Revolving Door Prohibitions, dostupno na: http:// www.ncsl.org/research/ethics/50-state-table-revolving-door-prohibitions.aspx, posjećeno 14.06.2017.

90 Prema zajedničkom izvješću zaklade Sunlight (Sunlight Foundation) i Centra za odgovornu politiku (Centre for Responsive Politics) iz 2015. godine, od 104 bivših kongresmena i kongresnog osoblja, 29 se bavilo odnosima s vladom, javnim poslovima ili su bili zaposleni kao savjetnici u društvima koja se bave lobiranjem, iako je samo trinaestorica bila prijavljena kao lobisti koji rade na oblikovanju politika Kongresa. Takvu situaciju Sunlight zaklada naziva „potajnim“ lobiranjem. Open Secrets, All Cooled Off: As Congress Convenes, Former Colleagues Will Soon be Calling From K Street, https://www.opensecrets.org/news/2015/01/ coming-out-of-the-cool-as-congress-convenes-former-colleagues-will-soon-be-calling-fromk-street/, posjećeno 12.11.2017. i L.A. Times, The revolving door spins faster: Ex-Congressmen become 'stealth lobbyists', http://www.latimes.com/business/hiltzik/la-fi-mh-the-revolvingdoor-20150106-column.html, posjećeno 12.11.2017.

91 The White House Office of the Press Secretary, President Trump's 100 Days of Accountability, dostupno na: https://www.whitehouse.gov/the-press-office/2017/04/27/president-trumps-100days-accountability, posjećeno 14.06.2017.

92 Huffpost, Trump Adding Former Lobbyists To Swamp, Giving Them Ethics Waivers, dostupno na: http://www.huffingtonpost.com/entry/trump-lobbyists-ethics-waivers us_58f43e1fe4b0b9e9848cc6c4, posjećeno 17.04.2017.

93 The Intercept, https://theintercept.com/2017/06/23/democratic-lobbyists-donald-trump-motturpodesta-comcast-prudential/, posjećeno 14.06.2017. 
dogovaranja susreta predsjednika Trumpa i predsjednika Republike Kongo. ${ }^{94} \mathrm{Tu}$ valja spomenuti i činjenicu da je bivši voditelj kampanje predsjednika Trupma, Paul Manafort, zajedno sa svojim poslovnim partnerom, Rickom Gatesom, optužen za nepravilnosti u objavljivanju podataka vezanih za lobiranje za strane vlade, što je bio dužan učiniti sukladno FARA-i, a što za Paula Millera, lobista koji predsjedava Nacionalnim institutom za lobiranje i etiku (National Institute for Lobbying and Ethics (NILE)), nepotrebno baca ružnu sjenu na lobiranje. ${ }^{95}$

\subsection{Lobiranje i ljudska prava}

Postoje tendencije daljnje i striktnije regulacije lobističke djelatnosti, pa je tako Američka odvjetnička komora 2011. godine oformila i radnu skupinu koja se uspjela usuglasiti oko nekoliko ključnih pitanja, uz potvrdu preko 400000 njezinih članova, ${ }^{96}$ što je i potvrđeno Rezolucijom ABA-e. ${ }^{97}$ Neki od prijedloga su zahtjevi da se pojedinci registriraju kao lobisti, ako „ostvare više od jednog lobističkog kontakta ili prime naknadu veću od 2.500 USD ili više od 10.000 USD po kvartalu ili provedu dvanaest ili više sati po kvartalu baveći se lobističkim djelatnostima. "98 U izvješćima koja moraju podnositi, trebalo bi navesti ,imena svih osoba koje pružaju bilo kakvu podršku lobiranju kroz strateško planiranje, odnose s javnošću ili operacije vezane uz glasovanje. “99 Američka odvjetnička komora izdala je i priručnike za lobiranje koji predstavljaju najsveobuhvatnije kompendije prakse i zakonodavstva vezanog za lobiranje. ${ }^{100}$

Pri pokušaju striktnije regulacije lobiranja, neminovno se nameću pitanja slobode govora te slobode slanja predstavki i pritužbi, koje propisuje i štiti Prvi amandman, a na koje zakonodavac pazi još od donošenja FRLA-e. Prema Allardu, Founding Fathers nisu smatrali pravo na slanje predstavki i pritužbi ,samo nezaobilaznim ili središnjim pravom nove Republike, već i elementom vladavine slobodnih ljudi.“ Osim toga ,pitanje lobiranja i njegova ustavnog statusa, sukladno gledištu Vrhovnoga suda, kompleksno je i nijansirano, no jasno je da Vrhovni sud priznaje lobiranje i

94 Vidi, primjerice: The Intercept, Prominent Democratic Fundraisers Realign to Lobby for Trump's Agenda https://www.wsj.com/articles/jack-abramoff-sought-meeting-with-trump-for-congosleader-1498251832, posjećeno 14.06.2017., The Center for Public Integrity, Federal Politics, Jack Abramoff is back — as a registered lobbyist, dostupno na: https://www.publicintegrity. org/2017/06/22/20942/jack-abramoff-back-registered-lobbyist, posjećeno 14.06.2017.

95 The New York Times, U.S. Lobbying Trade Group Urges Congress to Revamp Disclosure Laws, dostupno na: https://www.nytimes.com/reuters/2017/10/31/us/politics/31 reuters-usacongress-lobbying.html, posjećeno 12.11.2017.

96 American Bar Association, Lobbying in the Spotlight: Challenges and Proposed Improvements, Report of the Task Force on Federal Lobbying Law and Regulatory Practice, 2011.

97 Resolution, American Bar Association, Adopted By The House Of Delegates, August 8-9, 2011, dostupno na: https://www.americanbar.org/content/dam/aba/directories/policy/2011_am_104b. authcheckdam.pdf, posjećeno 12.11.2017.

98 The Campaign Legal Center, The Failure..., op. cit., str.4.

99 Loc. cit.

100 Gordon, Rebecca H. i Susman, Thomas M (ur.), A Complete Guide to Federal Lobbying Law and Practice, 5. izd., ABA Book Publishing, 2016. 
reguliranje lobiranja kao djelatnost obuhvaćenu Prvim amandmanom.“ ${ }^{101}$ Naime, u presudi Rumely v. United States, povezanom s FRLA-om, Sud je implicitno priznao da lobiranje ima pravo na zaštitu pod Prvim amandmanom, ${ }^{102}$ a u presudi United States v. Harris, povezanom s istim pravnim aktom, Sud je opet postavio ključno pitanje koja točno prava uživaju lobisti. ${ }^{103} \mathrm{U}$ kasnijem slučaju Regan $v$. Taxation with Representation of Washington spomenimo izdvojena mišljena sudaca Blackmuna, Brennana i Marshalla, koji su ponovili stajalište da je „lobiranje zaštićeno Prvim amandmanom. " ${ }^{104}$ Značajan je i daljnji razvoj tumačenja odnosa lobiranja i Prvog amandmana u slučaju Meyer v. Grant ${ }^{105}$ gdje Sud nalazi kako „Prvi amandman ne štiti samo pravo pojedinca da zagovara određeni interes, već i izbor što on smatra da je najprikladnije sredstvo za postizanje istoga, uključujući pravo na angažiranje lobista.“

Daljnji razvoj prakse Vrhovnog suda pokazuje doista zabrinjavajući trend. U slučaju FEC v. Wisconsin Right to Life ${ }^{106}$ iz 2007. godine Vrhovni je sud ustanovio kako Savezna izborna komisija „ne može temeljem Ustava zabraniti grassroots lobiranje poput televizijskih oglasa plaćenih od strane korporacija ili unija u tjednima prije izbora." Kao što je Sud objasnio, osim ako takvi oglasi izričito traže glasovanje za ili protiv određenog kandidata, njihova bi ograničenja predstavljala cenzuru temeljnog prava, tj. političkog govora. Konačno, nadaleko poznati slučaj Citizens United v. $F E C^{107}$ presedan je kojim je u ime slobode govora zaštićene Prvim amandmanom ukinuto ograničenje financijskih sredstava koje, između ostalog, i korporacije mogu utrošiti u političku kampanju. Krajnje je jasno: tko ima dovoljno novca, može ne samo izravno utjecati na izbor pojedinog kandidata, već osigurati i trajni pristup utjecaju na javnu politiku. Najpoznatiji kritičar ove prakse je upravo Chomsky, izjavljujući da „ono što se provodi kao politika uglavnom su napisali korporativni lobisti i odvjetnici koji dobiju pristup zahvaljujući donacijama." ${ }^{108} \mathrm{U}$ takvim je uvjetima upitna spremnost barem dijela kongresmena i predsjedničkih kandidata za otvoreniju borbu protiv neprimjerenih utjecaja.

\section{ZAKLJUČAK}

Može se uočiti da je jedno od glavnih obilježja demokracije - ujedno i njen condicio sine qua non - upravo pluralizam na kojem ona počiva. Demokracija je smislena ako pruža realne šanse zainteresiranima za sudjelovanje u procesu donošenja

101 Allard, Nicholas W., Lobbying is an honorable profession: the right to petition and the competition to be right, Bord of trustees of the Leland Stanford Junior University, vol. 19, br. 1, 2008., str. 38-39.

102 United States v. Rumely, 345 U.S. 41 (1953).

103 United States v. Haris, 347 U.S. 612 (1954).

104 Regan v. Taxation With Representation, 461 U.S. 540 (1983).

105 Meyer v. Grant, 486 U.S. 414 (1988).

106 FEC v. Wisconsin Right to Life, Inc., 551 U.S. 449 (2007).

107558 U.S. 310 (2010)

108 Chomsky, N., op. cit., str. 101. „Zakonodavci obično i ne znaju o čemu se radi, ali ljudi koji to vode - korporativni odvjetnici - utope ih u navodnim podacima, argumentima i tonama kojekakvog materijala. Zapravo, zakone pišu oni.“ 
odluka. Lobiranje je nezaobilazna pojava i djelatnost suvremene realizacije takvih šansi. Razvidna je stoga važnost odgovarajuće regulacije te aktivnosti. Problemi regulacije su, međutim, brojni. Iznimno je važno odrediti tko je zapravo lobist i tko se bavi lobiranjem, budući da prihvaćene definicije za sobom povlače brojne implikacije: od obveze prijave u registar transparentnosti preko prikazivanja financijskih podataka i njihovog obznanjivanja javnosti, pa sve do povećanja transparentnosti procesa donošenja odluka $\mathrm{i}$, naposljetku, distinkcije od korupcije kao ilegalne i zakonom kažnjive djelatnosti.

Početci lobiranja u Sjedinjenim Američkim Državama sežu još u osamnaesto i devetnaesto stoljeće, no prvi akt koji je regulirao lobiranje bio je Foreign Agents Registration Act iz 1938. godine, donesen radi sprječavanja širenja nacističke propagande u Sjedinjenim Američkim Državama te dodatno potaknut promjenama u načinu komuniciranja izazvanih pojavom radija i telefona. Nakon okončanja jednog od najstrašnijih događanja dvadesetog stoljeća, Drugog svjetskog rata, ponovno se prionulo na regulaciju lobiranja, što je urodilo vrlo opsežnim aktom dalekosežnijih pravnih posljedica od prijašnjega. Naime, u Federal Regulation of Lobbying Actu, dana je definicija lobista, a svaka ona osoba koja je odgovarala definiciji bila je dužna ne samo registrirati se, već i pružiti podatke koji se tiču izvora prihoda lobiranja i troškova. Nažalost, unatoč strogom slovu na papiru, sankcije kaznenopravne naravi u slučaju nepoštovanja odredaba zakona, a koje su uključivale čak i kaznu zatvora, u stvarnosti nisu zaživjele te predmetni zakon nije polučio željene rezultate.

Tek 1995. godine zakonodavstvo o lobiranju sveobuhvatnije je zahvaćeno reformom u vidu Lobbying Disclosure Acta, koji daje nove definicije ključnih pojmova ove djelatnosti, ali i pragove određivanja dopuštenih iznosa bez obveze registracije, odnosno čijim prelaskom registracija postaje nužna. Važno je i rješavanje pitanja registracije odvjetnika koji se bave lobiranjem, s obzirom na to da odvjetnici u jednom segmentu mogu pružati isključivo pravne usluge, dok u drugom zalaze u sferu lobiranja, pa se u potonjem slučaju ukazuje potreba registracije samom činjenicom prelaska pragova postavljenih zakonom, čime se ne utječe na odnos privatnosti između odvjetnika i klijenta.

Godina 2007. važna je zbog donošenja Honest Leadership and Open Government Acta, kojim se uvodi mogućnost online ispunjavanja prijave za registraciju, kao i poboljšane mogućnosti pretraživanja izvješća te njihovo učestalije podnošenje, a ograničava se i iznos vrijednosti darova za dužnosnike na koje se nastoji utjecati. Suvremene tendencije regulacije lobiranja u SAD-u teže $\mathrm{k}$ striktnijem pristupu, što najbolje potvrđuje inicijativa Američke odvjetničke komore iz 2011. godine, a posljednja dva američka predsjednika, Barack Obama i Donald Trump, obećali su razriješiti preostale boljke. Vidljivo je, međutim, da tendencije zlouporaba i dalje ostaju vrlo snažne, a sklonost aktera da djeluju u ,sivim zonama“ ostaje naglašena. Valja pratiti kako će se pravna regulacija lobiranja dalje razvijati, u nadi (možda i naivnoj) da se „umijeće uvjeravanja“ i stručnost njegovih nositelja etablira u svojoj profesionalnosti i multidisciplinarnosti kao ključan dio kreiranja javnih politika, ali ponajprije uz poštovanje ne samo slova, već i duha zakona. 


\section{LITERATURA}

\section{Knjige i članci}

1. Allard, Nicholas W., Lobbying is an honorable profession: the right to petition and the competition to be right, Bord of trustees of the Leland Stanfor Junior University, vol. 19, br. 1, 2008.

2. American Bar Association, Lobbying in the Spotlight: Challenges and Proposed Improvements, Report of the Task Force on Federal Lobbying Law and Regulatory Practice, 2011.

3. Chomsky, Noam, Rekvijem za američki san: deset principa koncentracije bogatstva i moći, Sandorf, Zagreb, 2017.

4. Cutlip, Scott M.; Center, Allen H.; Broom, Glen M., Odnosi s javnošću, 8. izd., Mate, Zagreb, 2003.

5. Davidson, Roger H., Oleszek, Walter J., Lee, Frances E., Congress and Its Members, CQ Press, Washington, 2012.

6. Gordon, Rebecca H. i Susman, Thomas M (ur.), A Complete Guide to Federal Lobbying Law and Practice, 5. izd., ABA Book Publishing, 2016.

7. Holman, Craig, Lobbying Reform in the United States and the European Union: Progress on Two Continents, Public Citizen, dostupno na: https://www.citizen.org/sites/default/ files/lobbying-reform-in-the-us-eu.pdf, posjećeno 12.06.2017.

8. Holman, Craig, Making the U.S. Lobbying Disclosure Act Work as Intended: Implications for the European Transparency Initiative, Public Citizen, 2007. dostupno na: https://www. citizen.org/sites/default/files/making-lda-work.pdf, posjećeno 5.06.2018.

9. Holman, Craig, Origins, Evolution and Structure of the Lobbying Disclosure Act, Public Citizen, 2006., dostupno na: http://www.consumerwatch.org/documents/Origins $\% 20$ of\%20Lobbying\%20Disclosure\%20Act.pdf, posjećeno 5.06.2018.

10. Kašćelan, Balša, Pravni okviri lobiranja, Izazovi evropskih integracija, Službeni glasnik, br. 4., 2009.

11. Maurer, William R., The Regulation of Grassroots Lobbying, Engage, 2010., vol. 11., br. 1.

12. Osredečki, Eduard, Odnosi s javnošću, Naklada Edo, Zagreb, 1995.

13. Tusinski Berg, Kati, Finding Connections Betwen Lobbying, Public Relations and Advocacy, Public Relations Jurnal, vol. 3., br. 3., 2009., http://epublications.marquette. edu/cgi/viewcontent.cgi?article=1081\&context=comm_fac, posjećeno 10. 07. 2017.

14. Vidačak, Igor, Lobiranje, Interesne skupine i kanali utjecaja u Europskoj uniji, Planetopija, Zagreb, 2007.

15. Vlahović, Natko, Jelić, Bruno, Profesionalni lobist, priručnik o interesnom zagovaranju, M.E.P., Zagreb, 2015.

Vrela s interneta

1. Bloomberg Business, A Brief History of Lobbying, dostupno na:

https:/www.bloomberg.com/news/articles/2012-06-07/a-brief-history-of-lobbying, posjećeno 11.06.2017.

2. Huffpost, Trump Adding Former Lobbyists To Swamp, Giving Them Ethics Waivers, dostupno na: http://www.huffingtonpost.com/entry/trump-lobbyists-ethics-waivers us_58f43e1fe4b0b9e9848cc6c4, posjećeno 17.04.2017.

3. Infoplease, Jack Abramoff, dostupno na: https://www.infoplease.com/people/who2biography/jack-abramoff, posjećeno 13.06.2017.

4. L.A. Times, The revolving door spins faster: Ex-Congressmen become 'stealth lobbyists', http://www.latimes.com/business/hiltzik/la-fi-mh-the-revolving-door-20150106-column. html, posjećeno 12.11.2017. 
5. National Conference of State Legislature, Revolving Door Prohibitions, dostupno na: http://www.ncsl.org/research/ethics/50-state-table-revolving-door-prohibitions.aspx, posjećeno 14.06.2017.

6. Open Secrets, All Cooled Off: As Congress Convenes, Former Colleagues Will Soon be Calling From K Street, https://www.opensecrets.org/news/2015/01/coming-out-ofthe-cool-as-congress-convenes-former-colleagues-will-soon-be-calling-from-k-street/, posjećeno 12.11.2017.

7. Open Secrets Org., Center for Responsive Politics, Glossary, dostupno na: https://www.opensecrets.org/lobby/lobby00/glossary.php, posjećeno 12.06.2017.

8. Political Law Blog, What is the Foreign Agents Registration Act (FARA)?, dostupno na: https://www.hklaw.com/politicallawblog/what-is-the-foreign-agents-registration-actfara-06-01-2016/, posjećeno 10.07.2017.

9. Politico, Revolving Door, dostupno na: http://www.politico.com/story/2015/12/barackobama-revolving-door-lobbying-217042, posjećeno 14.06.2017.

10. Priceonomics.com, When lobbying was illegal, https://priceonomics.com/when-lobbyingwas-illegal/, 28.10.2017.

11. Smith, R. Jeffrey, The Washington Post, In Jack Abramoff's memoir, 'Capitol Punishment,' an unrepentant reformer?, dostupno na:

https://www.washingtonpost.com/entertainment/books/in-jack-abramoffs-memoircapitol-punishment-an-unrepentant-reformer/2011/11/30/gIQAxZIpiO_story.html?utm_ term $=.04 \mathrm{~b} 14 \mathrm{cf} 5 \mathrm{dd} 4 \mathrm{c}$, posjećeno 13.06 .2017 .

12. Straus, Jacob R., The Lobbying Disclosure Act at 20: Analysis and Issues for Congress,Congressional Research Service, 2015., dostupno na: https://fas.org/sgp/crs/ misc/R44292.pdf, posjećeno 13.06.2017.

13. The Campaign Legal Center, The Failure of the Lobbying Disclosure Act (LDA) and Proposed Reforms, Washington DC, dostupno na:

http://www.campaignlegalcenter.org/sites/default/files/LDA $\% 20$ Fact $\% 20$ Sheet $\% 20$ FINAL\%207-28-15.pdf, posjećeno 13.06.2017.

14. The Intercept, https://theintercept.com/2017/06/23/democratic-lobbyists-donald-trumpmottur-podesta-comcast-prudential/, posjećeno 14.06.2017.

15. The New York Times, U.S. Lobbying Trade Group Urges Congress to Revamp Disclosure Laws, dostupno na: https:/www.nytimes.com/reuters/2017/10/31/us/politics/31 reutersusa-congress-lobbying.html, posjećeno 12.11.2017.

16. The Princeton Review - Lobbyist, dostupno na: https://www.princetonreview.com/ careers/88/lobbyist, posjećeno 11.06.2017.

17. The White House Office of the Press Secretary, President Trump's 100 Days of Accountability, dostupno na: https://www.whitehouse.gov/the-press-office/2017/04/27/ president-trumps-100-days-accountability, posjećeno 14.06.2017.

18. United States Senate, Registration Tresholds, dostupno na:

https://www.senate.gov/legislative/Public_Disclosure/new_thresholds.htm, posjećeno 09.11.2017.

19. United States Senate, Legislation and Records, Lobbying, dostupno na: https://www. senate.gov/legislative/common/briefing/Byrd_History_Lobbying.htm, posjećeno 11.06.2017.

20. U.S. House of Representatives, Office of the Clerk, Lobbying Disclosure Act Guidance, dostupno na:

https://lobbyingdisclosure.house.gov/amended_lda_guide.html, posjećeno 08.11.2017.

21. Young, Jeffrey, Lobbying Regulated to Prevent Abuse in US, Voa News, 23. 8. 2010., dostupno na: https://www.voanews.com/a/lobbying-regulated-to-prevent-abuse-inus-101407789/174277.html, posjećeno 10.06.2017. 
Pravni akti:

Države, Sjedinjene Američke:

1. Foreign Agents Registration Act, dostupno na: https://www.fara.gov/indx-act.html, posjećeno 12.06.2017.

2. Honest Leadership and Open Government Act, dostupno na: http://clerk.house.gov/ public_disc/PLAW-110publ81.txt, posjećeno 13.06.2017.

3. Resolution, American Bar Association, Adopted By The House Of Delegates, August 8-9, 2011, dostupno na: https://www.americanbar.org/content/dam/aba/directories/ policy/2011_am_104b.authcheckdam.pdf, posjećeno 12.11.2017.

Hrvatska, Republika: Zakon o javnoj nabavi, Narodne novine, br. 120/16.

Komisija, Venecijanska:

1. Izvješće Venecijanske komisije o pravnom okviru za regulaciju lobiranja u državama članicama Vijeća Europe (Venice Commission Report CDL-DEM(2011)002 on the legal framework for the regulation of lobbying in the Council of Europe member States)

Sudska praksa:

1. Federal Election Comm'n v. Wisconsin Right to Life, Inc. 551 U.S. 449 (2007), dostupno na: https://supreme.justia.com/cases/federal/us/551/449/, posjećeno 14.06.2017.

2. Meyer v. Grant 486 U.S. 414 (1988), dostupno na: https://supreme.justia.com/cases/ federal/us/486/414/case.html, posjećeno 14.06.2017.

3. Regan v. Taxation With Representation 461 U.S. 540 (1983), dostupno na: https://supreme. justia.com/cases/federal/us/461/540/case.html, posjećeno 14.06.2017.

4. United States v. Harriss, 347 U.S. 612 (1954), dostupno na: https://supreme.justia.com/ cases/federal/us/347/612/case.html, posjećeno 13.07.2017.

5. United States v. Rumely, 345 U.S. 41 (1953), dostupno na: https://supreme.justia.com/ cases/federal/us/345/41/case.html, posjećeno 10.11.2017. 


\author{
Sanja Barić* \\ Ana Acinger**
}

\title{
Summary
}

\section{LEGAL STATUS OF LOBBYISTS IN THE USA}

Recognizing the importance of lobbying in modern democratic countries and its inevitability in the decisions-making process from the lower - local, to the highest levels of authority, the authors display lobbying in the United States, starting from the fact that United States have early recognized the importance of lobbying and its regulation, aiming to decrease transparency. In this way, the authors go through relevant provisions of legal acts regulating the legal position of the lobbyist from the very beginnings to the present day, following and analyzing their advantages and disadvantages, and in particular the context of social reality as an impetus for further legislation. In this context, there is also a relationship between politics and lobbying, as well as the relationship of lobbying and fundamental human rights contained in the First Amendment of the US Constitution.

Keywords: lobbying, legal status of lobbyists, United States, constitutional rights, transparency, human rights.

\section{Zussamenfassung}

\section{RECHTSREGELUNG DES LOBBYISMUS IN DEN VEREINIGTEN STAATEN}

In Anerkennung der Bedeutung von Lobbyismus in modernen demokratischen Ländern und ihrer Unausweichlichkeit im Entscheidungsfindungsprozess von den unteren - lokalen bis zu den höchsten Autoritätsebenen, zeigen die Autoren Lobbyismus in den Vereinigten Staaten, ausgehend von der Tatsache, dass die Vereinigten Staaten frühzeitig die Bedeutung von Lobbying und ihrer Regulierung erkennen haben, um die Transparenz zu verringern. Auf diese Weise durchlaufen die Autoren relevante Bestimmungen von Rechtsakten, die die rechtliche Stellung des Lobbyisten von den Anfängen bis zur Gegenwart regeln, indem sie ihre Vor- und Nachteile verfolgen und analysieren, sowie insbesondere den Kontext der sozialen Realität als Anstoß für weitere Gesetzgebung. In diesem Zusammenhang gibt es auch eine Beziehung zwischen Politik und Lobbyismus sowie die Beziehung zwischen

* Sanja Barić, Ph. D., Full Professor, University of Rijeka, Faculty of Law; sbaric@pravri.hr.

** Ana Acinger, Legal Trainee at Attorney at Law; ana.acinger@gmail.com. 
Lobbying und grundlegenden Menschenrechten, die in der ersten Änderung der Verfassung enthalten sind.

Schlüsselwörter: Lobbying, Rechtsstellung der Lobbyisten, USA, Verfassungsrechte, Transparenz, Menschenrechte.

\section{Riassunto}

\section{LA DISCIPLINA GIURIDICA DELLA POSIZIONE DEI LOBBISTI NEGLI STATI UNITI D'AMERICA}

Riconoscendo l'importanza del lobbying nei paesi moderni democratici e la sua inevitabilità nel processo decisionale dal livello basso (locale), ai più alti livelli di autorità, gli autori mostrano il lobbismo negli Stati Uniti, a partire dal fatto che gli Stati Uniti hanno riconosciuto presto l'importanza di lobbying, in particolare la sua regolamentazione con l'obiettivo di trasparenza. In questo modo, gli autori citano i pertinenti regolamenti che regolano la posizione giuridica del lobbista, dagli inizi ad oggi, seguendo e analizzando i loro vantaggi e svantaggi, e in particolare il contesto della realtà sociale come incentivo per ulteriori legislazioni. In questo contesto, c'è anche un rapporto tra politica e lobbying, nonchè il rapporto di lobbying e diritti umani fondamentali contenuti nel Primo emendamento della Costituzione.

Parole chiave: lobbying, Stati Uniti, diritti costituzionali, trasparenza, diritti umani. 